\title{
DETERMINATION OF AFLATOXIN M1 IN MILK SAMPLES BY AN OWLS-BASED IMMUNOSENSOR
}

\author{
H. SZALONTAI $\mathrm{I}^{\mathrm{a}^{*}}$, A. KISS ${ }^{\mathrm{b}}$ and N. AdÁNYI ${ }^{\mathrm{b}}$ \\ ${ }^{\mathrm{a}}$ Food Science Institute, Eszterházy Károly College, H-3300 Eger, Leányka u. 6./G. Hungary \\ ${ }^{\mathrm{b}}$ National Agricultural Research and Innovation Centre, Food Science Research Institute, \\ H-1022 Budapest, Herman Ottó út 15. Hungary
}

(Received: 10 April 2014; accepted: 18 June 2014)

\begin{abstract}
An immunoreaction-based method was investigated for the detection of aflatoxin M1 (AFM1), which is the hydroxylated metabolite of aflatoxin B1 (AFB1). This mycotoxin may be found in milk and milk products obtained from livestock that have ingested contaminated feed. Quantitative analysis of AFM1 was carried out using indirect (competitive) immunoassay method, which can be used for low weight molecules. The real-time measurement was done with Optical Waveguide Lightmode Spectroscopy (OWLS) technique. After the optimization of the chemical and biochemical parameters (determination of the optimal concentration of the immobilized AFM1-protein conjugate, determination of the AFM1 antibody content of the samples, etc.) real samples were also examined. Three kinds of milk sample preparation methods (filtration, centrifugation, size exclusion centrifugation) and two dilution rates (100 and 200 fold) were compared. The presented competitive immunoassay method showed the best results when 100 fold diluted filtered or centrifuged milk samples were examined. The dynamic measuring ranges for AFM1 were $0.001-0.1 \mathrm{ng} \mathrm{ml}^{-1}$ and $0.0005-0.01 \mathrm{ng} \mathrm{ml}^{-1}$, respectively.

Keywords: Aflatoxin M1, Optical Waveguide Lightmode Spectroscopy, immunosensor, label-free, milk
\end{abstract}

AFM1 contamination of milk occurs after the metabolism of AFB1 by the cow. Even though the transformation from B1 form to M1 turns it about 10 times less toxic, it belongs to the most toxic mycotoxin class (ELSANHOTY et al., 2014). AFM1 is known for its carcinogenic and hepatotoxic effects (LizÁRraga-PAulín et al., 2011), moreover AFM1 is unfortunately relatively stable during milk storage and the production of various dairy products. For these reasons the maximum AFM1 levels in milk are regulated in many countries. As for the European Union, the current level for AFM1 is $0.05 \mu \mathrm{g} \mathrm{kg}^{-1}$ (EU Commission Regulation 466/2001).

The utilisation of rapid, selective, sensitive, and cost-effective assays to determine AFM1 levels would improve food safety significantly. There are currently several accepted measuring techniques available for determining AFM1. These include enzyme-linked immunosorbent assays (ELISAs) (RASTOGI et al., 2004) and traditional analytical methods, such as thin-layer chromatography (TLC) (Nesheim \& TRUCKSESS, 1986; KAMAR, 2006) and high-performance chromatography (HPLC) (DrAGACCI et al., 2001; BogNANNO et al., 2006). As for ELISAs, some colorimetric tests are commercially available for AFM1. These assays are commonly used in routine analysis as they are reliable and parallel examination of samples is possible. The drawbacks of these kits are the long incubation time, complex washing and mixing steps. Concerning chromatographic techniques, HPLC has become the

\footnotetext{
* To whom correspondence should be addressed . Phone: +36-36-520-400 (4212); e-mail: h.szalontai@ektf.hu
} 
most widespread. These methods are sensitive and accurate but require extensive sample preparation steps, well trained personnel, and expensive instrumentation.

In an approach to overcome the above mentioned problems, biosensors have come to the front as alternative tools in the field of AFM1 detection. There are DNA-based (SionTorou et al., 1998; DinckAYA et al., 2011) and cell-based sensors (LAROU et al., 2013) with electrochemical detection. As for selectivity and sensitivity, the work of DiNCKAYA and coworkers (2011) proved to be the best. A special ss-HSDNA probe-based impedimetric biosensor provided a linear response to AFM1 in the concentration range of 1-14 $\mathrm{ng} \mathrm{ml}^{-1}$.

Most of the reported AFM1 sensors are immunosensors, as the best selectivity can be achieved by using specific antibodies against the target molecule. For this reason, many immunosensors (BADEA et al., 2004; Micheli et al., 2005; PARKER \& ToTHILL, 2009) have been developed in the last decade. Although these methods showed good selectivity, each of them required enzyme-labelling and electrochemical detection. Their limits of detection (LOD) for AFM1 vary between 11 and $40 \mathrm{ng} \mathrm{kg}^{-1}$ in milk samples. Our aim was to develop a label-free immunosensor that combines the high selectivity and sensitivity of immuno-recognition with real-time detection. A competitive immunoassay based on OWLS technique has been developed for AFM1.

\section{Materials and methods}

\subsection{Materials}

AFM1, $\gamma$-aminopropyltriethoxysilane (APTS) and tris(hydroxymethyl)aminomethane (Tris) were purchased from Sigma-Aldrich (USA), polyclonal rabbit anti-AFM1 serum (85 mg $\mathrm{ml}^{-1}$ total protein content) against aflatoxin M1-bovine serum albumin (AFM1-BSA) immunogen from Agrisera (Sweden), coating antigen of aflatoxin M1-horseradish peroxidase (AFM1-HRP) conjugate ( $22 \mathrm{mg} \mathrm{ml}^{-1}$ total protein content) from R-Biopharm (Germany), 25\% aqueous solution of glutaraldehyde from Merck (Germany), $3 \mathrm{KDa}$ macrosep centrifugal device from Pall corporation (USA), qualitative filter paper (150 mm, $80 \mathrm{~g} \mathrm{~m}^{-2}$, particle retention 5-8 $\mu \mathrm{m}$ ) from VWR International (USA). All other reagents were of analytical grade and double distilled water was used in this research. The milk $(1.5 \%$ low-fat UHT) was purchased from a local store. Competitive ELISA test (Ridascreen Aflatoxin M1 test kit, R-Biopharm, Germany) was carried out in order to prove that the milk samples used for the calibration were AFM1 free. The same test kit has been used for the validation of the biosensor method.

\subsection{Instrumentation}

OWLS measurements were performed using amino functionalized integrated optical waveguide sensors (type OW 2400, MicroVacuum, Budapest, Hungary) containing optical grating on the top of the glass support. The sensor output was read with an OWLS120 instrument and BioSense 2.6.8 software (MicroVacuum Ltd, Budapest, Hungary) was used for data collecting. The temperature control unit (MicroVacuum Ltd, Budapest, Hungary) was connected to the OWLS system. All the experiments were carried out in flow injection analyzer system containing a syringe pump (NE-1000, NY, USA) and a built in injection valve (Rheodyne 9725, CA, USA) fitted with a $200 \mu 1$ sample loop. 


\subsection{AFM1-HRP immobilization and measuring method}

Before the measurements, amino functionalized $\mathrm{SiO}_{2}-\mathrm{TiO}_{2}$ sensor surface was prepared (TRUMmER et al., 2001). The silanization was followed by the activation of the sensor surface with $200 \mu \mathrm{l}$ of $2.5 \%$ glutaraldehyde, which was performed immediately before the AFM1HRP immobilization in flow through system. After stable baseline was obtained, AFM1-HRP conjugate solution was injected in an appropriate dilution. Finally, the distilled water was changed to the reaction buffer of $42 \mathrm{mmol}^{-1}$ Tris ( $\mathrm{pH} \mathrm{7.4)}$ ). At the end of the immobilization $10 \mathrm{mmol} 1^{-1} \mathrm{HCl}$ was injected to wash the surface. Followed by the baseline stabilization (approximately $10 \mathrm{~min}$ ), the system was ready for sample measurement. Upon the injection of the corresponding samples, $10 \mathrm{mmol}^{-1} \mathrm{HCl}$ was injected in order to dissociate the antigenantibody complexes, thus regenerating the sensor. The applied flow rate and temperature were $0.12 \mathrm{ml} \mathrm{min}^{-1}$ and $24{ }^{\circ} \mathrm{C}$, respectively, during all the measurements.

\subsection{Sample preparation}

Standard AFM1 solutions and milk samples were prepared for indirect measurements. Three different sample preparation methods were compared to eliminate the matrix effect of the remaining milk ingredients in the samples. First, milk was spiked with different concentrations of AFM1 (0.01-2000 ng ml-1), then simply filtered (particle retention 5-8 $\mu \mathrm{m}$ ), centrifuged $\left(3500 \mathrm{~g}, 10 \mathrm{~min}, 10^{\circ} \mathrm{C}\right.$ ), or size exclusion centrifuged ( $3 \mathrm{KDa}$ ultrafiltration membrane). Milk samples were diluted 50 or 100 fold (42 mmol $\mathrm{l}^{-1}$ Tris, $\mathrm{pH} \mathrm{7.4)} \mathrm{before} \mathrm{being} \mathrm{measured.}$ During the measurements, all samples were examined in three parallels.

\section{Results and discussion}

\subsection{Competitive measurement of AFM1}

For competitive measurements, AFM1-HRP conjugate was immobilized on the sensor surface as detailed in 1.3. The immobilization was followed by the examination of standards or milk samples (section 1.4.), which were mixed with the antibody solution of appropriate concentration in 1:1 ratio. After $3 \mathrm{~min}$ incubation $\left(24^{\circ} \mathrm{C}\right)$, the mixture was injected to the sensor surface. Applying this measuring method, only the antibodies remaining free in the sample mixture can bind to the antigens immobilized. So the amount of antibodies binding to the surface is inversely proportional to the quantity of the antigen in the standard solutions.

\subsection{Determination of the amount of the applied polyclonal serum}

The determination of the amount of the applied polyclonal serum is essential in the case of indirect measurements, as this is a rather sensitive equilibrium. Therefore the choice of the appropriate parameters is very important. For this examination, $3.0 \mu \mathrm{g} \mathrm{ml}^{-1}$ of AFM1-HRP conjugate was immobilized on the surface, according to the procedure described in 1.3. Antiserum against AFM1 was measured in different concentrations $(170,85,42.5,21.25$, and $8.5 \mu \mathrm{g} \mathrm{ml}^{-1}$ ) in order to determine the adequate antibody concentration. As it can be seen in Fig. 1, when there is a smaller amount of proteins $\left(8.5 \mu \mathrm{g} \mathrm{ml}^{-1}\right)$ in the solution, antibodies saturate poorly the surface, and small, unstable response can be obtained. In the case of higher concentrations $\left(170 ; 85 \mu \mathrm{g} \mathrm{ml}^{-1}\right)$, although the signal obtained is well measurable (about 30-40 arbitrary units), the surface becomes saturated, it loses its sensitivity during the 
measurement of standards and samples. For the measurements we chose the antiserum concentration that gives already well measurable signal (about 20 arbitrary units). On the other hand, this solution should not contain too many antibodies, so that it remains sensitive enough to detect standards containing low amounts of antigenes. Taking the height and shape of the signals into consideration, in the case of competitive measurement of AFM1, the concentration of the antibody solution was $21.25 \mu \mathrm{g} \mathrm{ml}^{-1}$.

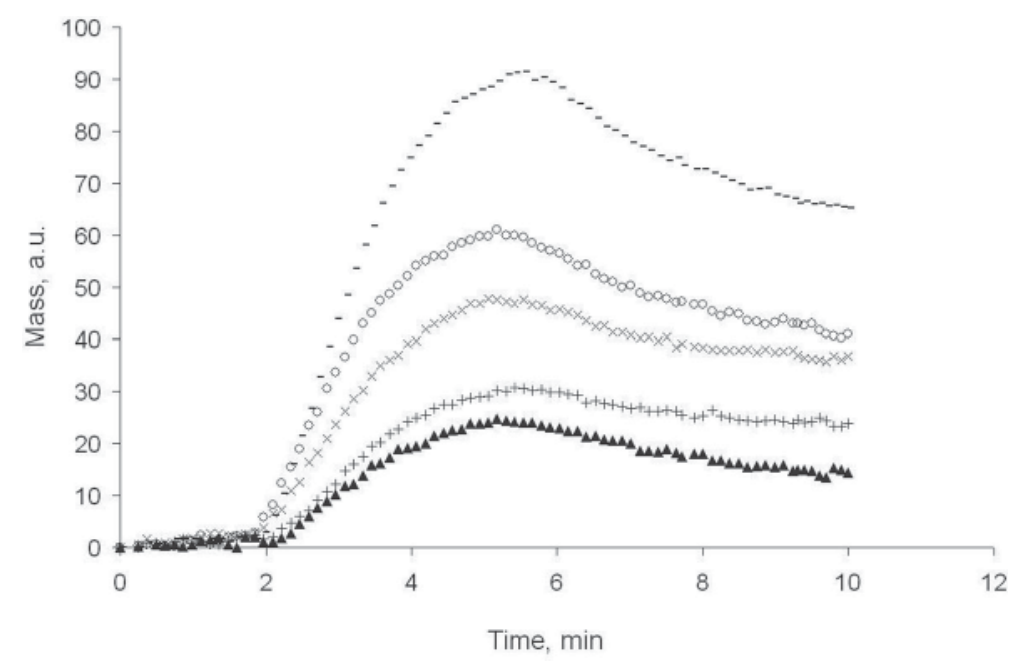

Fig. 1. Sensor responses of AFM1 antiserum at different concentrations $\left(\boldsymbol{\Delta}: 8.5 \mu \mathrm{g} \mathrm{ml}^{-1} ;+: 21.25 \mu \mathrm{g} \mathrm{ml}^{-1} ; \times: 42.5 \mu \mathrm{g} \mathrm{ml}^{-1} ; \circ: 85 \mu \mathrm{g} \mathrm{ml}^{-1} ;--: 170 \mu \mathrm{g} \mathrm{ml}^{-1}\right.$ )

\subsection{Determination of the optimal antigen conjugate concentration for immobilization}

In order to define the optimal AFM1-HRP coating, different concentrations $(2.2 ; 3.0$ and 4.4 $\mu \mathrm{g} \mathrm{ml}{ }^{-1}$ ) were immobilized on the sensor surface and tested with competitive AFM1 measurements. The antiserum of $42.5 \mu \mathrm{g} \mathrm{ml}^{-1}$ was mixed with the appropriate concentration of the AFM1 standard solutions $\left(0.0002-200 \mathrm{ng} \mathrm{m}^{-1}\right)$ and after the proper incubation, samples were measured. Figure 2 shows the effect of the concentration of AFM1-HRP conjugate immobilized on the sensor surface. Using $4.4 \mu \mathrm{g} \mathrm{ml}^{-1}$ conjugate, the sensor shows a narrow dynamic measuring range for AFM1 (0.01-1 $\left.\mathrm{ng} \mathrm{ml}^{-1}\right)$. At higher AFM1 concentrations the sensor became unstable. Applying the $3 \mu \mathrm{g} \mathrm{ml} \mathrm{m}^{-1}$ conjugate, the measuring range was between $0.001-100 \mathrm{ng} \mathrm{ml}^{-1}$ and the standard deviations were the lowest $( \pm 0.3-0.5$ a.u.) compared to the other two sensors $\left( \pm 0.4-1.2\right.$ a.u.). Although the $2.2 \mu \mathrm{g} \mathrm{ml}^{-1}$ antiserum showed the best sensitivity in the range of $0.001-0.1 \mathrm{ng} \mathrm{ml}^{-1}$ AFM1, the responses for higher AFM1 concentrations became unstable. Taking the results into consideration, $3 \mu \mathrm{g} \mathrm{ml}^{-1}$ AFM1-HRP conjugate was immobilized for further competitive measurements.

\subsection{AFM1 determination in milk samples}

The above detailed investigation was followed by the analysis of spiked milk samples, prepared as detailed in section 1.4. After dilution, the AFM1 concentration in the 100 and 200 fold diluted milk samples was between $0.0002-2 \mathrm{ng} \mathrm{ml}^{-1}$ and $0.0001-1 \mathrm{ng} \mathrm{ml}^{-1}$, respectively, whereas the antiserum concentration was the optimal concentration of $21.25 \mu \mathrm{g} \mathrm{ml}^{-1}$. 


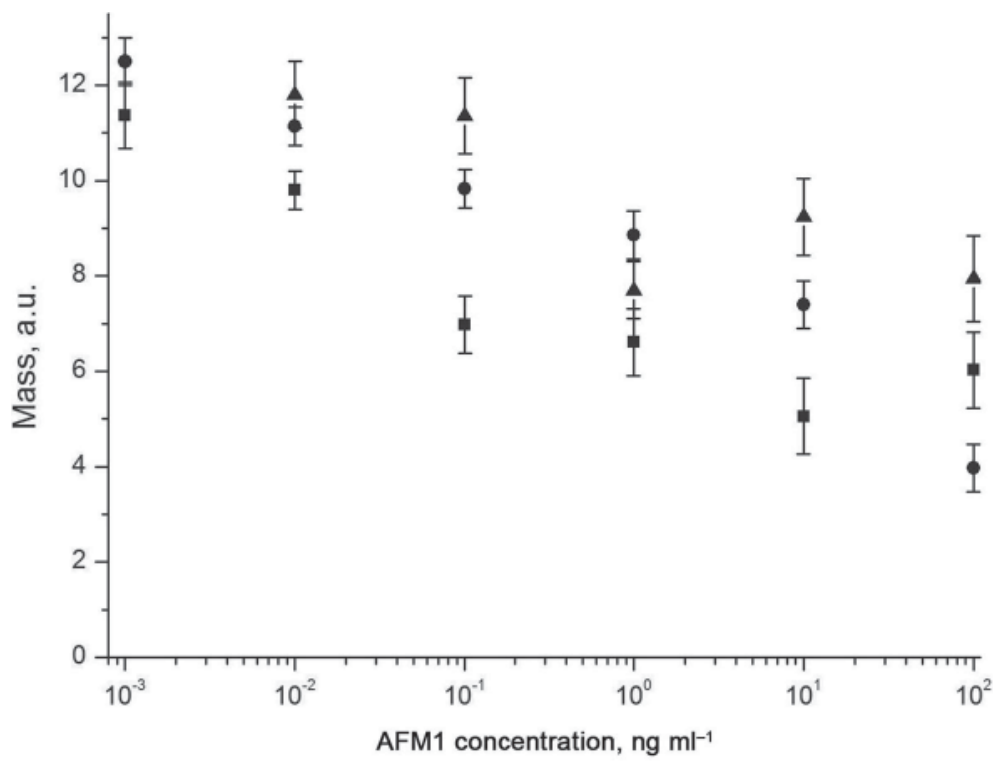

Fig. 2. Sensor responses at different concentrations of AFM1-HRP conjugate immobilized on the sensor surface

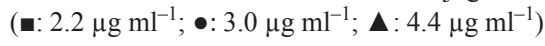

Figure 3 shows the sensor responses given by 100 fold diluted filtered, centrifuged, or size exclusion centrifuged milk samples. When measuring filtered milk samples, the dynamic detection range of AFM1 was found between 0.001 and $0.1 \mathrm{ng} \mathrm{ml} \mathrm{m}^{-1}, \mathrm{IC}_{50}$ was $0.016 \pm 0.002 \mathrm{ng} \mathrm{ml}^{-1}$, while the LOD was as low as $0.0005 \mathrm{ng} \mathrm{ml}^{-1}$. In case of centrifuged samples, the sensor proved to be more sensitive (LOD $0.0001 \mathrm{ng} \mathrm{ml}^{-1}$; dynamic measuring range $0.0005-0.01 \mathrm{ng} \mathrm{ml}^{-1}, \mathrm{IC}_{50}$ was $0.0021 \pm 0.0004 \mathrm{ng} \mathrm{ml} \mathrm{m}^{-1}$ ), but at lower AFM1 concentrations the relative standard deviation became slightly higher. During the third type of sample preparation, the spiked milk samples were centrifuged with size exclusion filter. As it can be seen in Figure 3, dynamic measuring range of AFM1 could not be observed in the concentration range studied. Using this process, all components higher than $3 \mathrm{KDa}$ molecular weight (mainly proteins) were eliminated from the milk. Due to its semipolar character, most of the AFM1 is associated with the nonfat milk solids (VAN EGMOND \& PAULSCH, 1986) in particular with casein (30\% estimated) (MoHAMMADI, 2011). As a consequence, AFM1 was removed together with the milk proteins. For this reason, size exclusion centrifugation of 3 $\mathrm{KDa}$ is not an applicable method to prepare milk samples for AFM1 biosensor measurements.

Measuring 200 fold diluted filtered samples (Fig. 4), the dynamic detection range was obtained between 0.0005 and $0.01 \mathrm{ng} \mathrm{ml}^{-1}, \mathrm{IC}_{50}$ was $0.00074 \pm 0.00010 \mathrm{ng} \mathrm{ml}^{-1}$. In the case of centrifuged samples, it was between 0.0001 and $0.001 \mathrm{ng} \mathrm{ml}^{-1}$, while $\mathrm{IC}_{50}$ was $0.00051 \pm 0.00008 \mathrm{ng} \mathrm{ml}^{-1}$. Taking the signals and the dynamic measuring range into consideration, it can be concluded that the 200 fold dilution resulted too weak signals in the concentration range of interest. 


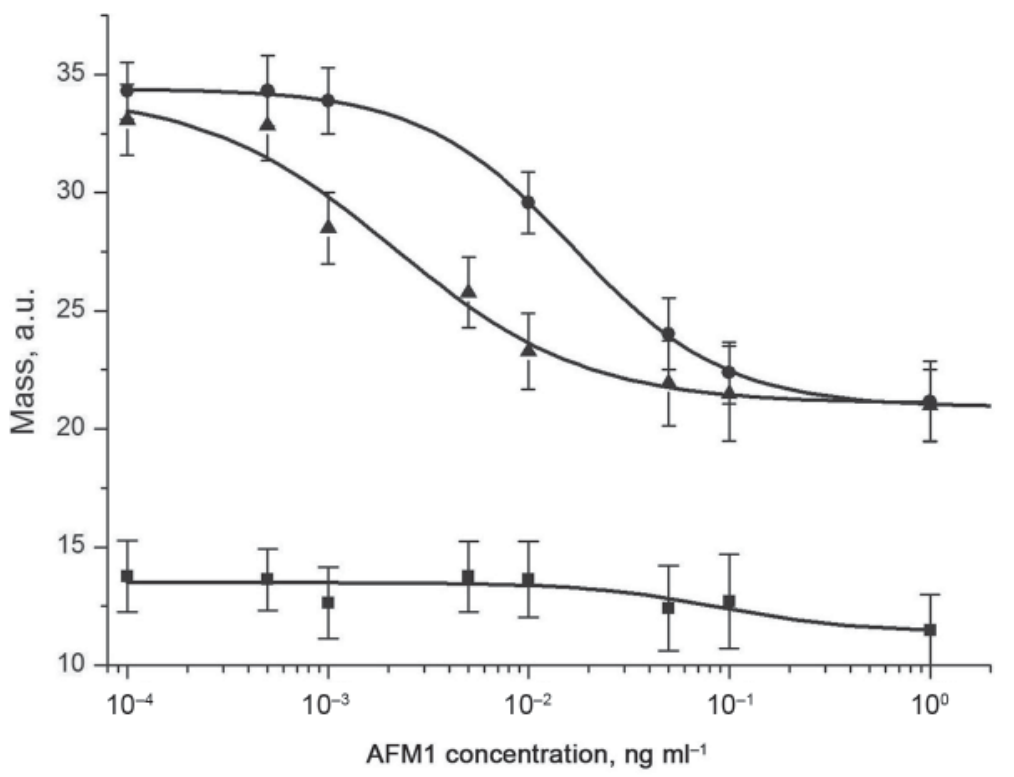

Fig. 3. Sensor responses of 100 fold diluted spiked milk samples prepared in three ways ( $3 \mu \mathrm{g} \mathrm{ml}^{-1}$ AFM1-HRP immobilized; $21.25 \mu \mathrm{g} \mathrm{ml}^{-1}$ AFM1 antiserum; $\boldsymbol{\Pi}$ : size-exclusion; $\bullet$ : filtered; $\boldsymbol{\Delta}$ : centrifuged)

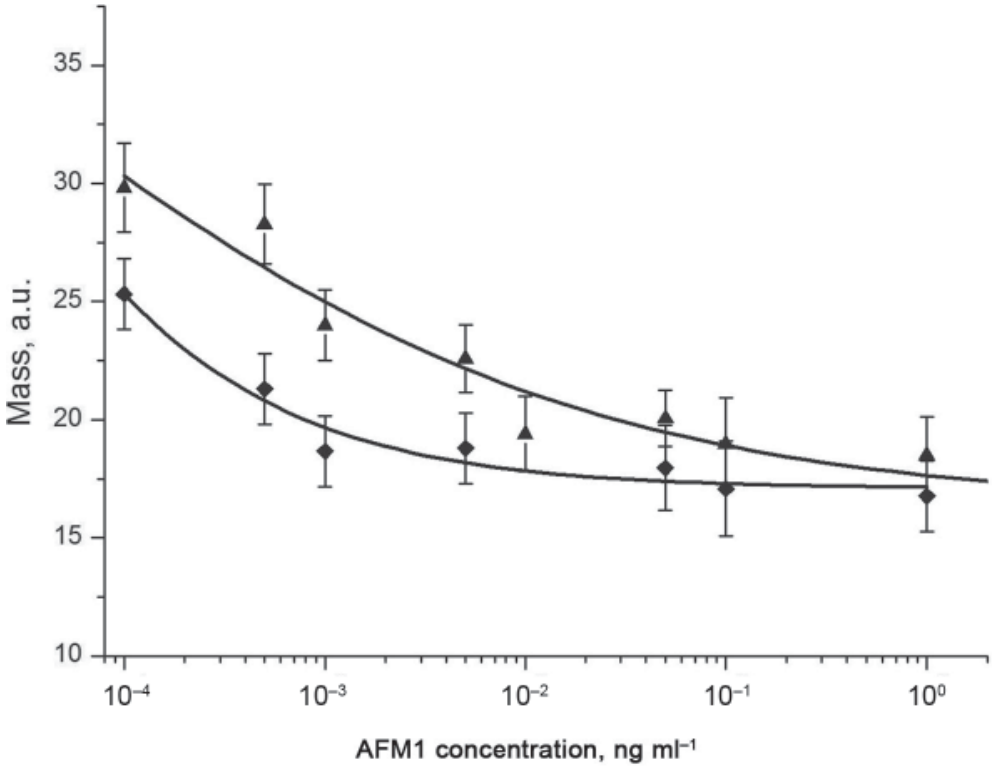

Fig. 4. Sensor responses of 200 fold diluted spiked milk samples prepared in two ways ( $3 \mu \mathrm{g} \mathrm{ml}^{-1}$ AFM1-HRP immobilized; $21.25 \mu \mathrm{g} \mathrm{ml}^{-1}$ AFM1 antiserum; $\boldsymbol{\Lambda}$ : filtered; $\bullet$ : centrifuged) 
According to the results, the sensor showed the best sensitivity and stability when applying 100 fold dilution of milk and using filtration or centrifugation. By utilizing the above detailed measuring parameters, the improved OWLS-based method is about one order of magnitude more sensitive than those obtained with similar competitive immunosensors using electrochemical detection (BADEA et al., 2004; Micheli et al., 2005; PARKer \& TothilL, 2009).

Competitive ELISA format was used to validate the results of the biosensor measurements. Filtered and centrifuged milk samples containing 0.01 and $0.05 \mathrm{ng} \mathrm{ml}^{-1}$ AFM1 were measured. The results obtained by the immunosensor were compared to those measured by ELISA and summarized in Table 1. The results are in accordance with each other, indicating the reliability of the AFM1 immunosensor when measuring 100 fold diluted milk samples. The best results were obtained when filtered samples were used for the measurement. This result underlines again that AFM1 toxin could associate with milk proteins and AFM1 bound proteins are partly removed from the milk sample during the centrifugation sample preparation step.

Table 1. The average value of measured Aflatoxin M1 content in 100 fold diluted milk samples

\begin{tabular}{lccc}
\hline Sample & $\begin{array}{c}\text { Aflatoxin M1 } \\
\text { concentration in milk } \\
\left(\mathrm{ng} \mathrm{ml}^{-1}\right)\end{array}$ & ELISA & OWLS \\
\hline Filtered milk & 0.010 & $0.012 \pm 0.001$ & $0.010 \pm 0.001$ \\
Centrifuged milk & 0.050 & $0.054 \pm 0.002$ & $0.048 \pm 0.003$ \\
& 0.010 & $0.008 \pm 0.001$ & $0.012 \pm 0.001$ \\
& 0.050 & $0.042 \pm 0.003$ & $0.039 \pm 0.002$ \\
\hline
\end{tabular}

\section{Conclusions}

The elaboration of a competitive method for AFM1 detection has been presented in this work, based on non-labelled OWLS detection. First, the optimization of the major measuring parameters, such as immobilized AFM1-HRP conjugate concentration $\left(3.0 \mu \mathrm{g} \mathrm{ml}^{-1}\right)$ and the applied antiserum concentration $\left(21.25 \mu \mathrm{g} \mathrm{ml}^{-1}\right)$ was carried out. Then, spiked milk samples, prepared in three ways (filtration, centrifugation, and size exclusion centrifugation), were examined. Comparing these procedures and 100 or 200 fold dilutions of the samples, it can be concluded, that the best results were obtained when 100 fold diluted filtered or centrifuged samples were measured. In the case of filtered milk samples, AFM1 could be detected in the range of $0.001-0.1 \mathrm{ng} \mathrm{ml}^{-1}$ with $0.0005 \mathrm{ng} \mathrm{m}^{-1} \mathrm{LOD}$. As for centrifuged milk samples, the LOD was as low as $0.0001 \mathrm{ng} \mathrm{ml}^{-1}$ and the dynamic measuring range was found between $0.0005-0.01 \mathrm{ng} \mathrm{ml}^{-1}$. According to the results, the novel label-free immunosensor is applicable for the quick determination of AFM1 contamination in milk samples.

Financial support from TÁMOP-4.1.1.C-12/1/KONV-2012-0014 is greatly acknowledged. 


\section{References}

Badea, M., Micheli, L., Messia, C.M., Candigliota, T., Marconi, E., Mottram, T., Velasco-Garcia, M., Moscone, D. \& Palleschi, G. (2004): Aflatoxin M1 determination in raw milk using a flow-injection immunoassay system. Anal. Chim. Acta, 520, 141-148.

Bognanno, M., La Fauci, L., Ritieni, A., Tafuri, A., De Lorenzo, A., Micari, P., Di Renzo, L., Ciappellano, S., Sarullo, V. \& Galvano, F. (2006): Survey of the occurrence of aflatoxin M1 in ovine milk by HPLC and its confirmation by MS. Mol. Nutr. Food Res., 50, 300-305.

Dinckaya, E., Kinik, Ö., Sezgintürk, M.K., Altug, C. \& AkкocA, A. (2011): Development of an impedimetric aflatoxin M1 biosensor based on a DNA probe and gold nanoparticles. Biosens. Bioelectron., 26, 3806-3811.

Dragacci, S., Grosso, F. \& Gilbert, J. (2001): Immunoaffinity column cleanup with liquid chromatography for determination of aflatoxin M1 in liquid milk: Collaborative study. J. AOAC Int., 84, 437-443.

Elsanhoty, R.M., Salam, S.A., Ramadan, M.F. \& Badr, F.H. (2014): Detoxification of aflatoxin M1 in yoghurt using probiotics and lactic acid bacteria. Food Control, 43, 129-134.

European Commission (2001): Human-and-animal-health-an-emerging-problem. Commission Regulation 466/2001, Off. Eur. Comm. L77 (2001) p. 7.

Kamar, A. (2006): A study on the occurrence of aflatoxin M1 in Iranian Feta cheese. Food Control, 17, 768-775.

Larou, E., Yiakoumettis, I., Kaltsas, G., Petropoulos, A., Skandamis, P. \& Kintzios, S. (2013): High throughput cellular biosensor for the ultra-sensitive, ultra-rapid detection of aflatoxin M1. Food Control, 29, 208-212.

Lizárraga-Paulín, E.G., Moreno-Martínez, E. \& Miranda-Castro, S.P. (2011): Aflatoxins and their impact on human and animal health: an emerging problem, aflatoxins. -in: GuEvarA-GonZALEz, R.G. (Ed.) Biochemistry and molecular biology. Available at: http://www.intechopen.com/books/aflatoxins-biochemistry-andmolecular-biology/aflatoxins-and-their-impact-on-human-health-an-emerging-problem

Micheli, L., Grecco, R., Badea, M., Moscone, D. \& Palleschi, G. (2005): An electrochemical immunosensor for aflatoxin M1 determination in milk using screen-printed electrodes. Biosens. Bioelectron., 21, 588-596.

Mohammadi, H. (2011): A review of aflatoxin M1, milk, and milk products, aflatoxins. -in: GuEvara-GonZALEZ, R.G. (Ed.) Biochemistry and molecular biology. Available at: http://www.intechopen.com/books/aflatoxinsbiochemistry-and-molecular-biology/a-review-of-aflatoxin-m1-milk-and-milk-products

Nesheim, S. \& TRucksess, M.W. (1986): Thin layer chromatography/High -performance thin layer chromatography as a tool for mycotoxin determination. -in: Cole, R.J. (Ed.) Modern methods in the analysis and structural elucidation of mycotoxins. Academic Press Inc., Orlando, USA, pp. 241-252.

PARKer, C.O. \& Tothill, I.E. (2009): Development of an electrochemical immunosensor for aflatoxin M1 in milk with focus on matrix interference. Biosens. Bioelectron., 24, 2452-2457.

Rastogi, S., Dwivedi, P.D., Khanna, S.K. \& Das, M. (2004): Detection of aflatoxin M1 contamination in milk and infant milk products from Indian markets by ELISA. Food Control, 15, 287-290.

Siontorou, C.G., Nikolelis, D.P., Miernik, A. \& Krull, U.J. (1998): Rapid methods for detection of aflatoxin M1 based on electrochemical transduction by self-assembled metal-supported bilayer lipid membranes (s-BLMs) and on interferences with transduction of DNA hybridization. Electrochim. Acta, 43, 3611-3617.

Trummer, N., AdÁnyi, N., VÁradi, M. \& Szendrö, I. (2001): Modification of the surface of integrated optical waveguide sensors for immunosensor applications. Fresen. J. Anal Chem, 371, 21-24.

Van Egmond, H.P. \& Paulsch, W.E. (1986): Mycotoxins in milk and milk products. Neth. Milk Dairy J., 40, 175188. 